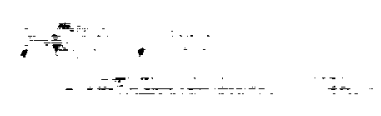

NASA Technical Memorandum 105832

\section{$1 N=3$ \\ 117608}

\title{
Monolithic and Mechanical Multijunction Space Solar Cells
}

Raj K. Jain and Dennis J. Flood

Lewis Research Center.

Cleveland, Ohio

August 1992

(NASA-TM-105832) MONOLITHIC AND

MECHANICAL MULTIJUNCTION SPACE

SOLAR CELLS (NASA) $13 \mathrm{p}$
N92-32233

Unclas 


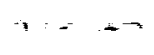

$\ldots \ldots \ldots \ldots \ldots$

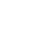

$-\therefore-\cdots-\cdots$

$+\cdots+\cdots+\cdots+\cdots$ 


\title{
MONOLITHIC AND MECHANICAL MULTIJUNCTION SPACE SOLAR CELLS
}

\author{
Raj K. Jain ${ }^{*}$ and Dennis J. Flood \\ NASA Lewis Research Center \\ 21000 Brookpark Road \\ Cleveland, OH 44135
}

\section{SUMMARY}

High-efficiency, lightweight, radiation-resistant solar cells are essential to meet the large power requirements of future space missions. Single-junction cells are limited in efficiency. Higher cell efficiencies could be realized by developing multijunction, multibandgap solar cells. Monolithic and mechanically stacked tandem solar cells surpassing single-junction cell efficiencies have been fabricated. This article surveys the current status of monolithic and mechanically stacked multibandgap space solar cells, and outlines problems yet to be resolved. The monolithic and mechanically stacked cells each have their own problems related to size, processing, current and voltage matching, weight, and other factors. More information is needed on the effect of temperature and radiation on the cell performance. Proper reference cells and fullspectrum range simulators are also needed to measure efficiencies correctly. Cost issues are not addressed, since the two approaches are still in the developmental stage.

\section{INTRODUCTION}

High-efficiency, lightweight, radiation-resistant solar cells are essential to meet the large power requirements of future space missions. Such solar cells are being developed, and presentday laboratory results are quite promising. However, single-junction cells are limited in efficiency. Large-area silicon cells $(8 \mathrm{by} 8 \mathrm{~cm})$ to be used in the solar arrays for the Space Station Freedom are on the average 14.5 percent AMO efficient and have achieved efficiencies as high as 15.4 percent AMO (Khemtong et al., 1989). Currently, gallium arsenide (GaAs) single-junction solar cells have the highest energy conversion efficiency, and some test cells have flown successfully on various space flights.

GaAs cells $\left(4 \mathrm{~cm}^{2}\right)$ have achieved 1-sun efficiencies exceeding 21 percent AM0 (Bertness et al., 1989) and 25.1 percent AM0 at 333 suns, respectively, for $0.126 \mathrm{~cm}^{2}$ Cassegrainian cells (Hamaker et al., 1988). Their better radiation resistance would make them a strong candidate for future space satellite applications, if the cost could be brought down. Efforts in this direction have led to the development of GaAs cells on silicon (Si) and germanium (Ge) substrates. Fan and Palm (1983) performed a computer analysis to find the maximum achievable AMO efficiencies in single-junction crystalline cells as a function of the material energy bandgap, as shown in Fig. 1 for various sun concentrations at $80^{\circ} \mathrm{C}$. According to this figure, the optimally designed efficiencies at 1 sun are slightly more than 20 percent and for concentrations more than 500 suns are slightly above 25 percent. Efficiencies at $25{ }^{\circ} \mathrm{C}$ would be correspondingly higher. Therefore, it becomes quite clear that one could not achieve efficiencies in the 30 to 40 percent $A M 0$ range with single-junction devices alone.

Higher cell efficiencies could be achieved by more effectively utilizing more of the sunlight energy spectrum. This could be accomplished through the use of more than one active junction

\footnotetext{
"National Research Council-NASA Research Associate at Lewis Research Center.
} 
of different bandgaps in a solar cell device. In fact, as early as 1955, Jackson (1955) suggested that the cell efficiency could be increased through the use of different bandgap materials, but because of the complexity and economic reasons, the approach was not pursued. Moon et al. (1978) were the first to demonstrate this concept experimentally by using a spectral-splitting filter and a two-cell $\mathrm{Si}$ and aluminum gallium arsenide (AlGaAs) arrangement. Although this approach required complex optical elements, it clearly illustrated the viability of the multibandgap concept by achieving 28.5 percent efficiency (AM1.23, 165 suns). This approach could be implemented practically by fabricating either monolithic or mechanically stacked (MS) tandem multijunction solar cells. Theoretically, any number of active junctions of different bandgap materials could be considered. In such cells, light not absorbed in the high-bandgap top junction is transmitted down to the bottom junction, and the process continues. Figures 2 and 3 show the AM0 isoefficiency plots of the two-cell, monolithic (two-terminal) and mechanically stacked (four-terminal) tandem structures at $27^{\circ} \mathrm{C}$ and 1 sun, respectively (Fan et al., 1982). Figures 4 and 5 describe the AM0 isoefficiency plots of the two-cell, monolithic and the MS tandem structures at $80^{\circ} \mathrm{C}$ and 100 suns (Fan and Palm, 1983). These results are from a computer analysis to determine the maximum achievable efficiencies of tandem cells by optimal bandgap combinations of cell materials. From figures 2 to 5 it is clear that tandem cell efficiencies in excess of 30 percent AM0 could be achieved. Efficiencies around 40 percent AM0 are expected for three-cell tandem cell structures according to a computer optimal design study (Fan and Palm, 1983).

In this article, attempts are made to survey the present status of monolithic and MS multibandgap space solar cells. The goal has been to achieve 30 percent plus AM0 with twojunction cells and 40 percent plus AM0 efficiencies with three-junction tandem cells. Theoretical calculations and cell modeling have also predicted efficiencies in these ranges. The results are very encouraging and promise a great potential for using these cells in future space power systems. Although tandem cells for terrestrial applications (AM1.5) have not been considered in this work, significant progress has been reported recently (Gee and Virshup, 1988, and Fraas et al., 1990), and both technologies are complementing the overall development.

The next two sections review the recent developments in monolithic and MS stacked multibandgap, multijunction tandem solar cells, respectively, for space applications. The status of concentrator cell technology also is discussed. Prismatic cover slides are being used to effectively eliminate grid-shading losses, leading to improved efficiencies. Tandem cells in thin-film form are being developed to achieve high specific power. The discussion section opens up several questions about what efficiencies could be practically achieved, which structure - monolithic or mechanically stacked - is better, and other concerns. Both the monolithic and MS cells have their own problems, and efforts are made to outline problems yet to be resolved. Recommendations for further work also are highlighted. Cost issues have not been resolved since the two approaches are still in the developmental stage.

\section{MONOLITHIC TANDEM CELLS}

Conceptually, the process of growing differing bandgap material junctions (one on top of the other) on a single substrate looks like a very elegant approach to fabricating monolithic tandem cells. An intermediate, transparent shorting layer interconnects the junctions, so that a two-terminal device is produced with the current of each junction matched to that of the other. In this approach, one could encounter interfering growth conditions (such as lattice and thermal expansion mismatch, auto doping, and out diffusion) while growing different bandgap materials. 
The shorting layer must have low electrical and optical losses. Efforts have been made to produce two- and three-junction monolithic tandem cells for space applications; so far, the results have been encouraging.

Lillington et al., (1989) reported a typical AM0 efficiency of 19.1 percent $\left(28^{\circ} \mathrm{C}\right)$ on 2 - by $2-\mathrm{cm}^{2} \mathrm{GaAs} / \mathrm{Ge}$ dual-junction cells. Figure 6 shows the cross section of a GaAs/Ge cell. It is possible to improve efficiencies up to 24 percent AMO by using proper antireflection coatings, improving the quality of the GaAs growth/Ge wafers, and using back surface field/back surface reflector (BSF/BSR) in the Ge cell. Recently, Wojtczuk et al. (1991) reported a record efficiency of 23.4 percent AMO at 9 suns and $25^{\circ} \mathrm{C}$ for a monolithic, two-terminal $\mathrm{GaAs} / \mathrm{Ge}$ tandem space concentrator cell. Graded bandgap AlGaAs/Ge cells offering improved minoritycarrier collection have also been fabricated (Timmons et al., 1989), and the initial results are encouraging. Timmons et al. (1989) observed that AlGaAs cells are more radiation-resistant than GaAs cells. Germanium offers a good lattice and thermal match, allowing growth of highquality GaAs and AlGaAs layers. Ge wafers also offer lower cost and mechanically strong, lighter (thin) cells. Recently, Wanlass et al. (1990) reported the development of a latticematched indium phosphide/gallium 0.47 indium 0.53 arsenide $\left(\operatorname{InP} / \mathrm{Ga}_{0.47} \operatorname{In}_{0.53} \mathrm{As}\right)$ two-junction, three-terminal, monolithic tandem cell with AM0 efficiencies of 23.9 percent $\left(25^{\circ} \mathrm{C}\right)$. The performance parameters of the best cell are described in Table I. The top InP cell offers the best radiation resistance, and the three-terminal structure provides independent control of each subcell in the monolithic stack. The cell efficiency improves to 28.8 percent AM0 at 40.3 suns. Partain et al. (1990) described the three-junction, two-terminal AlGaAs/GaAs/InGaAs monolithic concentrator solar cell for space applications. They achieved an efficiency of 15.3 percent for a 1.9-eV AlGaAs top cell, 9.9 percent for a 1.4-eV GaAs middle cell, and 2.4 percent for a 1.0-eV InGaAs bottom cell at $80^{\circ} \mathrm{C}$ and 100 suns. The total tandem AM0 efficiency for this $0.2-\mathrm{cm}^{2}$ monolithic three-junction cell adds to 27.6 percent. Further developments are in progress to achieve 30 percent AM0 efficiency cells.

\section{MECHANICALLY STACKED TANDEM CELLS}

The approach of mechanically stacking one cell over the other greatly expands the range of materials useful for tandem cell configurations. Therefore, well-developed individual cell technologies could be combined to construct high-efficiency MS multibandgap tandem cells without worrying about interfering growth conditions, shorting layers, or matching the current of subcells.

DiNetta et al. (1989) reported the development of a self-supporting, transparent AlGaAs top solar cell, which could be stacked on any well-developed bottom solar cell, and they predicted that efficiencies in the range of 30 to 40 percent AMO could be feasible with a concentrator system. Avery, J.E. et al., 1989, achieved a remarkable 30.8 percent AM0 $\left(25^{\circ} \mathrm{C}\right)$ efficiency at a 100-sun concentration by using mechanically stacked, transparent GaAs and gallium antimonide ( $\mathrm{GaSb}$ ) solar cells. Table II shows the stacked GaAs/GaSb test article performance data measured at the NASA Lewis Research Center. GaSb was preferred as a bottom cell over Ge because it is a binary compound, direct-gap material with a high absorption coefficient and has an appropriate bandgap energy of $0.72 \mathrm{eV}$.

The top cell is made by growing epitaxial layers over a GaAs wafer. This transparent cell does not have back grid lines and has antireflection coatings on the top and bottom surfaces to improve the transmission of the long-wavelength spectrum. Lower bulk doping $\left(1 \times 10^{17} \mathrm{~cm}^{-3}\right)$ 
has been used to reduce the free-carrier absorption. The bottom cell is made by a conventional diffusion process using single-crystal GaSb wafers. From Table II, it is observed that the cell fill factor (FF) is limited because of series resistance, and with further developments in processing, improvements in efficiency are expected. These cells are the same size and have an active area of $0.049 \mathrm{~cm}^{2}$ on a $0.3-$ by $0.5-\mathrm{cm}$ chip. The cells are assembled together in a test article to form the mechanically stacked tandem configuration. Each cell has an Entech cover, which avoids grid-line shading, as illustrated in Fig. 7. The GaAs and GaSb cells have different voltages and currents at the maximum power points, so they cannot be connected in series. Cells have to be interconnected in voltage-matched circuit configurations as discussed in the next section.

The other significant development is reported by Kim et al. (1989) on the fabrication of thin-film MS gallium arsenide/copper indium selenide ( $\mathrm{GaAs} / \mathrm{CuInSe}_{2}$ ) (tandem-junction) solar cells. The top cell is made of GaAs Cleaved Lateral Epitaxial Films for Transfer (CLEFT) thin film, and the bottom cell is a polycrystalline CuInSe ${ }_{2}$ thin film deposited on a glass substrate. More details about cell materials and processing are available in Kim et al. (1989). GaAs has good radiation resistance, but $\mathrm{CuInSe}_{2}$ has shown superb radiation tolerance (Burgess et al., 1988), which makes it one of the possible space-qualified materials for solar cells. The best efficiency achieved on these $4-\mathrm{cm}^{2}$ tandem cells is 23.1 percent AMO at 1 sun and is the highest efficiency ever reported for a thin-film cell. Figure 8 shows the I-V characteristics for the top GaAs and the bottom CuInSe ${ }_{2}$ cell measured at NASA Lewis. Improvements in efficiency up to 26 percent are projected by using AlGaAs as the absorber in the top cell. A comparison of the thin-film cell technology used in this tandem structure with a number of other technologies clearly demonstrated a significant array-level weight and area savings. GaAs/CuInSe ${ }_{2}$ tandem cells with $25-\mu \mathrm{m}$ - (1-mil-) thick cover glass could provide a specific power of $442 \mathrm{~W} / \mathrm{kg}$, which could be further improved to $750 \mathrm{~W} / \mathrm{kg}$ by using an AlGaAs top cell. For any space mission, solar array weight has a very deciding role, therefore thin-film solar cell technology offers a great potential.

\section{DISCUSSION}

Monolithic and mechanically stacked tandem cells have been developed with encouraging efficiencies, and further developments would boost the practical efficiencies to theoretical limits. However, most of the efforts are in the early stages, therefore many questions are unsolved and still need to be understood, discussed, and answered. Some of the points that require attention follow.

\section{Monolithic Versus Mechanically Stacked Cells}

If the growth of different bandgapmaterials were a simple process, the monolithic approach would be elegant. The MS concept offers the following advantages: (1) It avoids the directcontact growth of different materials with interfering growth conditions; (2) it eliminates the transparent shorting layer; (3) it removes the requirement of subcell current matching; and (4) it makes possible the use of a greatly expanded range of well-developed materials. Computer calculations have predicted better efficiencies for the MS cells in comparison to monolithic cells. Whereas MS cells require complicated antireflection coatings to achieve better optical coupling, monolithic cells require well-controlled epitaxial growth. Both approaches have resulted in cells with AMO efficiencies around 30 percent, and performance is expected to increase further with the proposed cell material and process developments. Therefore, it looks to be too early to decide which approach is best for space. However, it is clear that to improve efficiencies the concentrator approach would be desirable and should be pursued rigorously. Prismatic covers to 
improve grid-coverage losses should be incorporated. Present-day cells are mostly small in area, and efforts will be required to increase the size while maintaining the same efficiency. In the case of MS cells, the back-surface contact grid lines of the top cell could be aligned with the front-surface grid lines of the top and bottom cell, respectively, to minimize the losses. High specific weight is one of the most important criteria for any space satellite application. Thinfilm cells in an MS structure have shown great potential to meet the goal; therefore, cells should be developed using advanced CLEFT, peeled, or other new thin-film technologies.

\section{Temperature and Radiation Effects}

Solar cells for space missions are required to operate at high temperatures and in a harsh radiation environment. Therefore, it is necessary to study the behavior of tandem cells at temperatures to $100^{\circ} \mathrm{C}$ and with radiation damage equivalent to $1 \mathrm{MeV}$ electron up to $1 \times 10^{16}$ $\mathrm{cm}^{-2}$ and $10 \mathrm{MeV}$ protons up to $1 \times 10^{13} \mathrm{~cm}^{-2}$. Cell degradation due to temperature and radiation is very important to meet the space power requirement because the cell array is designed according to end-of-life (EOL) efficiencies. InP (Yamaguchi et al., 1984; Weinberg et al., 1985) and $\mathrm{CuInSe}_{2}$ (Burgess et al., 1988) have shown excellent radiation resistance, and cells based on these materials should be further pursued. InP, GaAs and AlGaAs have also shown better radiation resistance in comparison to $\mathrm{Si}$. Use of concentrated light would increase the cell operating temperature and should be considered while designing the solar array. Presently limited information (I-V characteristics, spectral response, etc.) is available on the temperature and radiation effects, and more work is required to determine the performance of tandem cells under these conditions.

\section{Tandem Cell Testing}

An accurate determination of tandem multijunction solar cell efficiency is very important to calculating the space array size. Methods to measure the I-V characteristics of single-junction solar cells under any reference spectrum are well established. In case of tandem-junction cells, especially for monolithic, two-terminal devices in which subcells are connected in series, the current mismatch between the individual cells would be different under the source and reference spectrum. This problem poses an uncertainty in evaluating monolithic cells correctly. Testing of tandem cells also requires calibrated reference cells. NASA Lewis Research Center has been providing single-junction and multijunction reference cells (AMO) by using its high-altitude airplane calibration technique. As newer tandem cells are developed, cells of each material must be calibrated. There is a need for a centralized facility for uniform standardized reliable testing of space-quality cells. Full-spectrum range simulators also must be developed. An improved method for determining tandem-cell efficiency by obtaining spectral mismatch between the individual subcells and the effect of solar simulators on the solar cell performance has been described in detail in Glatfelter and Burdick (1987) and Emery et al. (1988), respectively.

\section{Tandem Cell Integration In Arrays}

The space solar array design would require a number of cells/strings connected in series and parallel connections, along with power-conditioning equipment, to meet the load requirement. In the case of monolithic tandem cells, each subcell would degrade in a different way with the space radiation and temperature as a function of time. Therefore, the two-terminal, monolithic cell 
performance would be controlled primarily by the mismatch in individual cell currents. Mechanically stacked tandem cells could be controlled separately, but because the operating voltages and currents of the individual component cells are different, cells have to be connected in a voltage-matched $(m \times n)$ configuration to form a two-terminal device. Two-terminal, voltage-matched (3 by 3) configuration circuit cards utilizing GaAs/GaSb (Avery et al., 1989) and $\mathrm{GaAs} / \mathrm{CuInSe}_{2}$ (Kim et al., 1989) MS tandem cells, respectively, have been fabricated. Gee and Curtis (1988) calculated the effect of radiation on the various multijunction solar cell module configurations. A number of different concentrator cells were considered under the $1-\mathrm{MeV}$ electron irradiation up to a fluence of $3 \times 10^{15} \mathrm{~cm}^{-2}$. It was found that the module configuration can have a significant effect on the radiation tolerance of tandem cells because of the different rate of degradation for the voltage and current. A voltage-matched configuration was found to be superior to the series configuration, although it was difficult to simulate on-orbit conditions to study the circuit performance, especially for tandem cells.

\section{Cost}

Several types of monolithic and mechanically stacked tandem-junction solar cells have been developed with encouraging results. The present-day efforts are mostly at the laboratory level; therefore, it is too soon to estimate the projected costs per watt for tandem cells and to predict which approach - monolithic or MS - would be cost effective. Reliable cost estimates for space power cells could only be obtained after knowing the beginning-of-life (BOL) as well as EOL efficiencies, which will require more experiments on the effects of a space mission environment on the cells. The cell weight would also have a significant effect on the overall space array cost. High-efficiency, thin-film MS tandem multijunction cells offer a good promise toward higher power/weight and higher power/area solar arrays, leading to lower costs.

\section{CONCLUSIONS}

Monolithic and mechanically stacked tandem solar cells have been fabricated with encouraging AMO efficiencies, which are summarized in Table III.

(1) Significant improvements in tandem cell efficiencies nearing theoretical predictions are projected with improvements in cell material quality and processing. Thin-film tandem cells offer improved specific power.

(2) More information is required to determine the effects of temperature and radiation on the performance of tandem cells.

(3) It is too early to decide which configurations would be preferable: monolithic (two or three terminals), mechanical stack (four terminals), planar, or concentrator.

(4) Calibrated tandem reference cells and advanced solar simulators are necessary for accurate determinations of cell efficiencies.

(5) It is too soon to estimate projected costs per watt for tandem cells. 


\section{REFERENCES}

Avery, J.E., et al.: Tandem Concentrator Solar Cells with 30 Percent (AM0) Power Conversion Efficiency, Space Photovoltaic Research and Technology, NASA CP-3107, 1989, pp. 77-87.

Bertness, K.A., et al.: High Efficiency, Radiation-Resistant GaAs Space Cells," Space Photovoltaic Research and Technology, NASA CP-3107, 1989, 1989, pp. 136-139.

Burgess, R.M., et al.: Electron and Proton Radiation Effects on GaAs and CuInSe 2 Thin Film Solar Cells, IEEE Photovoltaic Specialists Conference, 20th, Vol. 2, IEEE, New York, 1988, pp. 909-912.

DiNetta, L.C., et al.: AlGaAs Top Solar Cell for Mechanical Attachment in a Multi-Junction Tandem Concentrator Solar Cell Stack, Space Photovoltaic Research and Technology Conference, NASA CP-3107, 1989, pp. 60-72.

Emery, K.; Myers, D.; and Rummel, S.: Solar Simulation-Problems and Solutions, IEEE

Photovoltaic Specialists Conference, 20th, Vol. 2, IEEE, New York, 1988, pp. 1087-1091.

Fan, J.C.; and Palm, B.J.: Optimal Design of High-Efficiency Single-Junction and Tandem Concentrator Space Cells at $80^{\circ} \mathrm{C}$ and 100 Suns, Space Photovoltaic Research and Technology, NASA CP-2314, 1984, pp. 120-127.

Fan, J.C.; Tsaur, B.Y.; and Palm, B.J.: Optimal Design of High-Efficiency Tandem Cells. IEEE Photovoltaic Specialists Conference, 16th, IEEE, New York, 1982, pp. 692-701.

Fraas, L.M., et al: Over 35-Percent Efficient GaAs/GaSb Tandem Solar Cells. IEEE Trans. Electron Devices, vol. 37, Feb. 1990, pp. 443-449.

Gee, J.M.; and Curtis, H.B.: The Effect of Different Module Configurations on the Radiation Tolerance of Multijunction Solar Cells. IEEE Photovoltaic Specialists Conference, 20th, vol. 2, IEEE, New York, 1988, pp. 996-1001.

Gee, J.M.; and Virshup, G.F.: A 31 Percent-Efficient GaAs/Silicon Mechanically Stacked, Multijunction Concentrator Solar Cell: IEEE Photovoltaic Specialists Conference, 20th, vol. 1, IEEE, New York, 1988, pp. 754-758.

Glatfelter, T.; and Burdick, J.: A Method for Determining the Conversion Efficiency of MultipleCell Photovoltaic Devices. IEEE Photovoltaic Specialists Conference, 19th, IEEE, New York, 1987, pp. 1187-1193.

Hamaker, H.C., et al: 25 Percent-Efficient GaAs Cassegrainian Concentrator Cell. Space Photovoltaic Research and Technology, 1988: High Efficiency Space Environment, and Array Technology, NASA CP-3030, 1989, pp. 292-297.

Jackson, E.D.: Areas for Improvement of the Semiconductor Solar Energy Converter. Transactions of the Conference on the Use of Solar Energy--The Scientific Base, Vol. 5, E.F. Carpenter, ed., University of Arizona Press, Tucson, AZ, 1958, pp. 122-126. 
Khemtong, S.; Hansen, N.; and Bower, M.; Optimization and Performance of Space Station Freedom Solar Cells. Space Photovoltaic Research and Technology, NASA CP-3107, 1989, pp. $400-409$.

Kim, N.P., et al.: Progress in GaAs/CuInSe 2 Tandem Junction Solar Cells. Space Photovoltaic Research and Technology, NASA CP-3107, 1989, pp. 88-101.

Lillington, D.R., et al.: Progress Toward the Development of Dual Junction GaAs/Ge Solar Cells. Space Photovoltaic Research and Technology, NASA CP-3107, 1989, pp. 29-41.

Moon, R.L., et al.: Multigap Solar Cell Requirements and the Performance of AlGaAs and Si Cells in Concentrated Sunlight. IEEE Photovoltaic Specialists Conference, 13th, IEEE, New York, 1978, pp. 859-867.

Partain, L.D., et al.: Progress Toward a 30 Percent Efficient, Monolithic, Three-Junction, TwoTerminal Concentrator Solar Cell for Space Applications. IEEE Photovoltaic Specialists Conference, 21st, Vol. 1, IEEE, New York, 1990, pp. 184-189.

Timmons, M.L., et al: Graded-Bandgap AlGaAs Solar Cells for AlGaAs/Ge Cascade Cells. Space Photovoltaic Research and Technology, NASA CP-3107, 1989, pp. 48-59.

Wanlass, M.W., et al.: Monolithic InP/ $/ \mathrm{Ga}_{0.47} \mathrm{In}_{0.53}$ As Tandem Solar Cells for Space. Space Photovoltaic Research and Technology, NASA CP-3121, 1991, pp. 16-1 to 16-10.

Wojtczuk, S., et al.: Monolithic Two Terminal GaAs/Ge Tandem Space Concentrator Cells. IEEE Photovoltaic Specialists Conference, 22nd, IEEE, New York, 1991, pp. 73-79.

Weinberg, I., et al.: Potential for Use of InP Solar Cells in the Space Radiation Environment. IEEE Photovoltaic Specialists Conference, 18th, IEEE, New York, 1985, pp. 1722-1724.

Yamaguchi, M., et al.: Electron Irradiation Damage in Radiation-Resistant InP Solar Cells. Japan. J. App. Phys., pt. 1, vol. 23, 1984, pp. 302-307. 
TABLE I.-MEASURED PERFORMANCE PARAMETERS FOR THE MOST EFFICIENT InP $/ \mathrm{Ga}_{0.47} \mathrm{In}_{0.53}$ AS THREE-TERMINAL

TANDEM CELL AT AMO AND $25^{\circ} \mathrm{C}$.

\begin{tabular}{|l|c|c|c|c|c|}
\hline Cell & $\begin{array}{c}\text { Open-circuit } \\
\text { voltage, } \\
\mathrm{V}_{\text {oc }}(\mathrm{V})\end{array}$ & $\begin{array}{c}\text { Short-circuit } \\
\text { current density, } \\
\mathrm{J}_{\mathrm{sc}}\left(\mathrm{mA} / \mathrm{cm}^{2}\right)\end{array}$ & $\begin{array}{c}\text { Fill factor, } \\
\text { FF (\%) }\end{array}$ & $\begin{array}{c}\text { Efficiency } \\
(\%)\end{array}$ & $\begin{array}{c}\text { Tandem } \\
\text { efficiency } \\
(\%)\end{array}$ \\
\hline $\mathrm{InP}$ & 0.880 & 34.4 & 82.9 & 18.3 & \\
$\mathrm{Ga}_{0.47} \mathrm{In}_{0.63} \mathrm{As}$ & 0.344 & 31.3 & 71.0 & 5.6 & 23.9 \\
\hline
\end{tabular}

TABLE II.-MEASURED MECHANICALLY STACKED GaAs/GaSb TEST ARTICLE PERFORMANCE DATA AT AMO, $25^{\circ} \mathrm{C}$, and 100 SUNS.

\begin{tabular}{|c|c|c|c|c|c|}
\hline Cell & $\begin{array}{c}\text { Short-circuit } \\
\text { current, } \\
\mathrm{I}_{\mathrm{sc}}(\mathrm{mA})\end{array}$ & $\begin{array}{c}\text { Open-circuit } \\
\text { voltage, } \\
\mathrm{V}_{\mathrm{oc}}(\mathrm{V})\end{array}$ & $\begin{array}{c}\text { Fill factor, } \\
\text { FF (\%) }\end{array}$ & $\begin{array}{c}\text { Efficiency } \\
(\%)\end{array}$ & $\begin{array}{c}\text { Tandem } \\
\text { efficiency } \\
(\%)\end{array}$ \\
\hline $\mathrm{GaAs}$ & 183 & 1.120 & 0.84 & 23.9 & $>$ \\
$\mathrm{GaSb}$ & 125 & 0.469 & 0.71 & 6.9 & 30.8 \\
\hline
\end{tabular}

TABLE III.-SUMMARY OF TANDEM SOLAR CELL EFFICIENCIES.

\begin{tabular}{|l|c|c|c|c|}
\hline $\begin{array}{c}\text { Type of } \\
\text { cell }\end{array}$ & Material & $\begin{array}{c}\text { Efficiency } \\
(\%)\end{array}$ & $\begin{array}{c}\text { Temperature } \\
\left({ }^{\circ} \mathrm{C}\right)\end{array}$ & $\begin{array}{c}\text { Cell area } \\
\left(\mathrm{cm}^{2}\right)\end{array}$ \\
\hline Monolithic & $\mathrm{GaAs} / \mathrm{Ge}$ & 19.1 & 28 & 4.0 \\
Monolithic & $\mathrm{InP} / \mathrm{Ga}_{0} .4 \mathrm{In}_{0.53} \mathrm{As}$ & 23.9 & 25 & 0.296 \\
Monolithic & $\mathrm{AIGaAs} / \mathrm{GaAs} / \mathrm{InGaAs}$ & $27.6(100$ suns $)$ & 80 & 0.2 \\
MS & $\mathrm{GaAs} / \mathrm{GaSb}$ & $30.8(100$ suns $)$ & 25 & 0.049 \\
MS & $\mathrm{GaAs} / \mathrm{CuInSe}$ & 23.1 & 25 & 4.0 \\
\hline
\end{tabular}




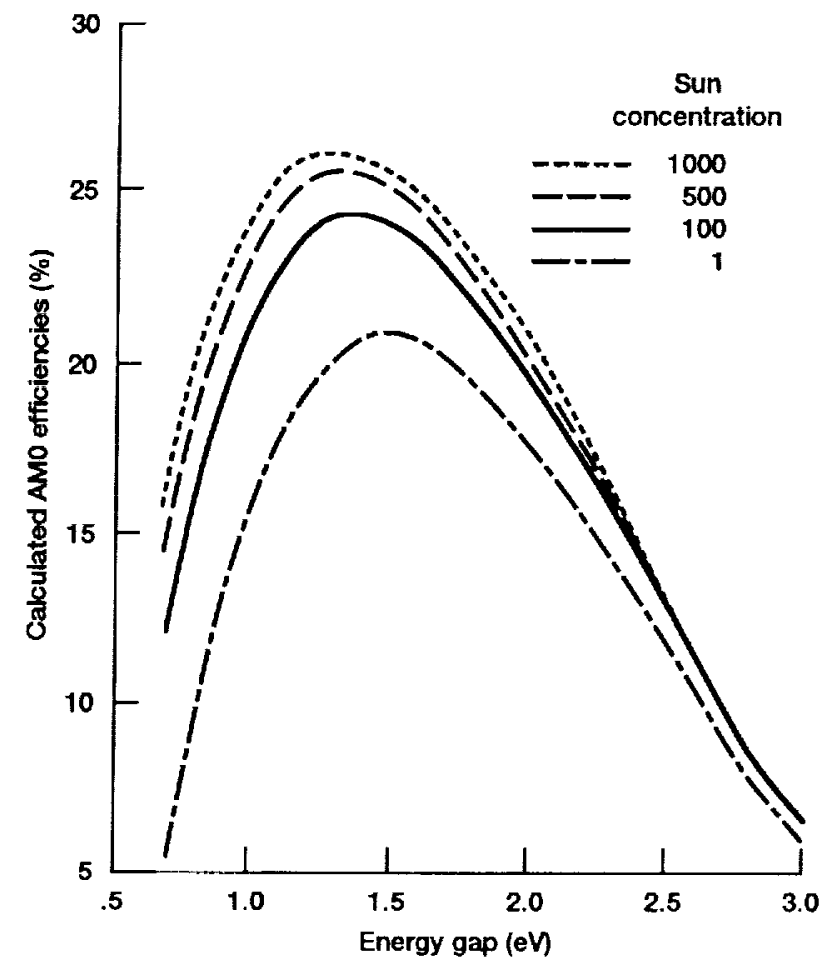

Figure 1.-Calculated AMO conversion efficiencies at 1-sun, 100 sun, 500-sun, and 1000-sun concentrations of single-junction solar cells made of materials having various bandgap energies. Operating temperature, $80^{\circ} \mathrm{C}$.

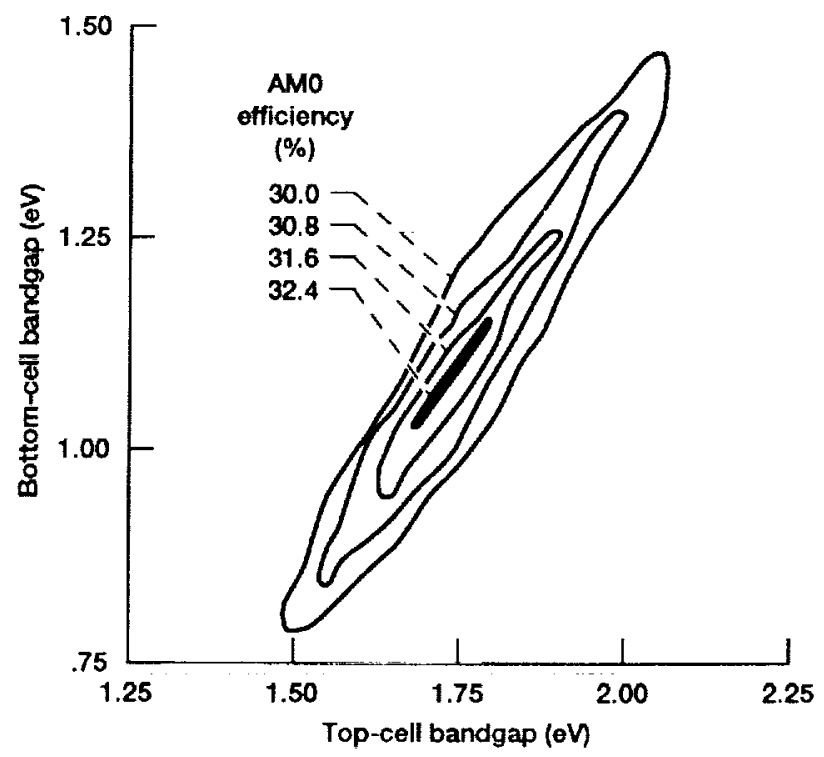

Figure 2.-Calculated AMO isoefficiency plots for two-cell, twoterminal tandem structure at $27^{\circ} \mathrm{C}$ and 1 sun.

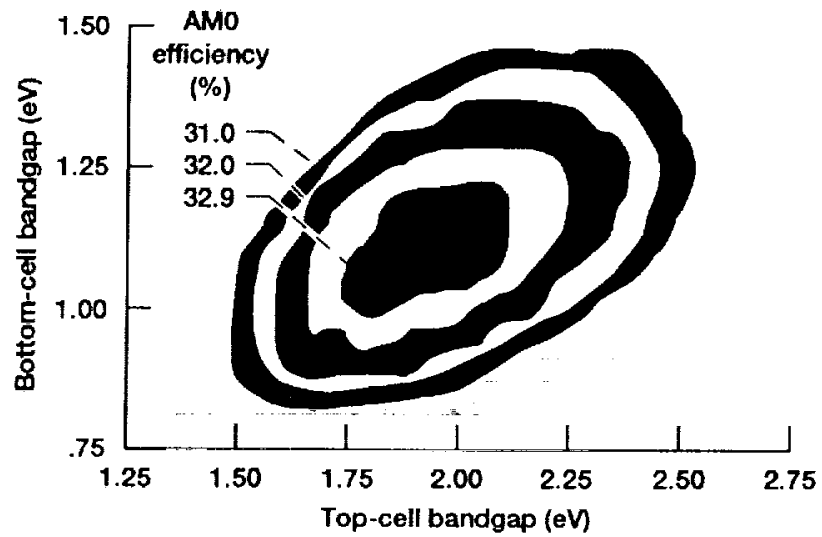

Figure 3.-Calculated AMO isoefficlency plots for two-cell, fourterminal tandem structure at $27^{\circ} \mathrm{C}$ and 1 sun.

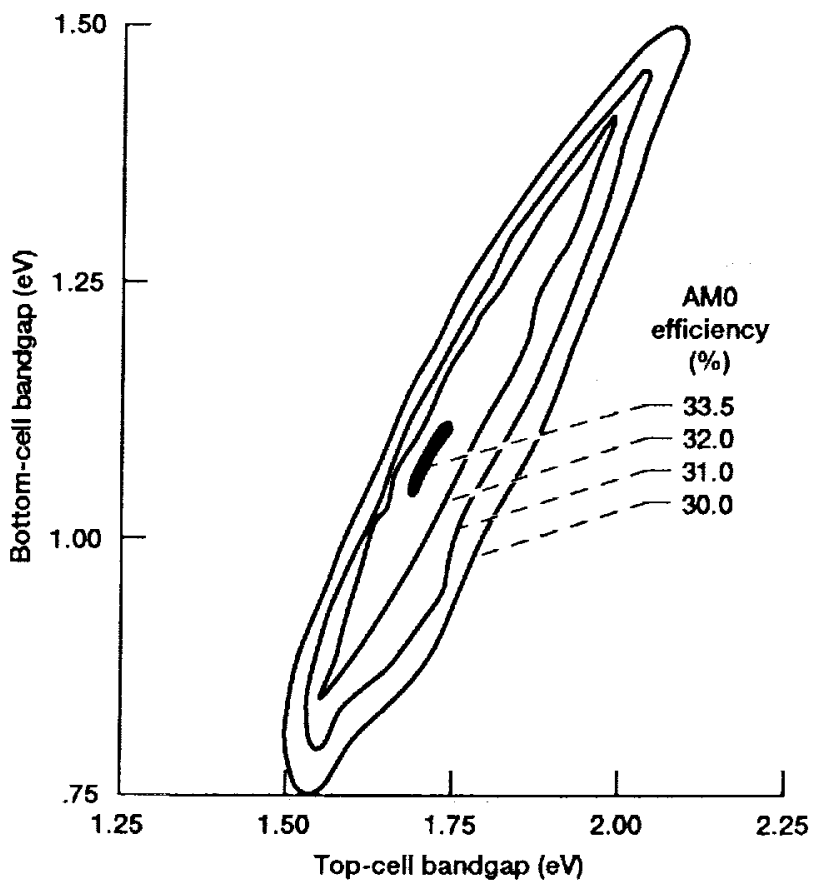

Figure 4.-Calculated AMO, 100-sun isoefficiency plots for twocell, two-terminal tandem structure at $80^{\circ} \mathrm{C}$. 


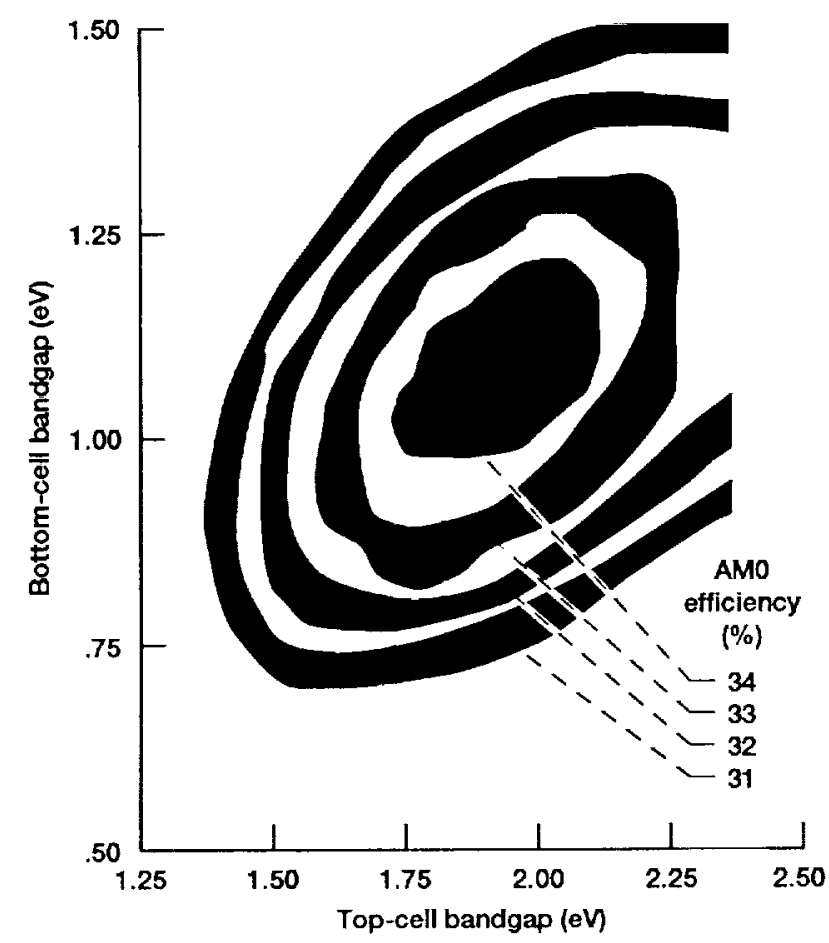

Figure 5.-Calculated AMO, 100-sun isoefficiency plots for twocell, four-terminal tandem structure at $80^{\circ} \mathrm{C}$.

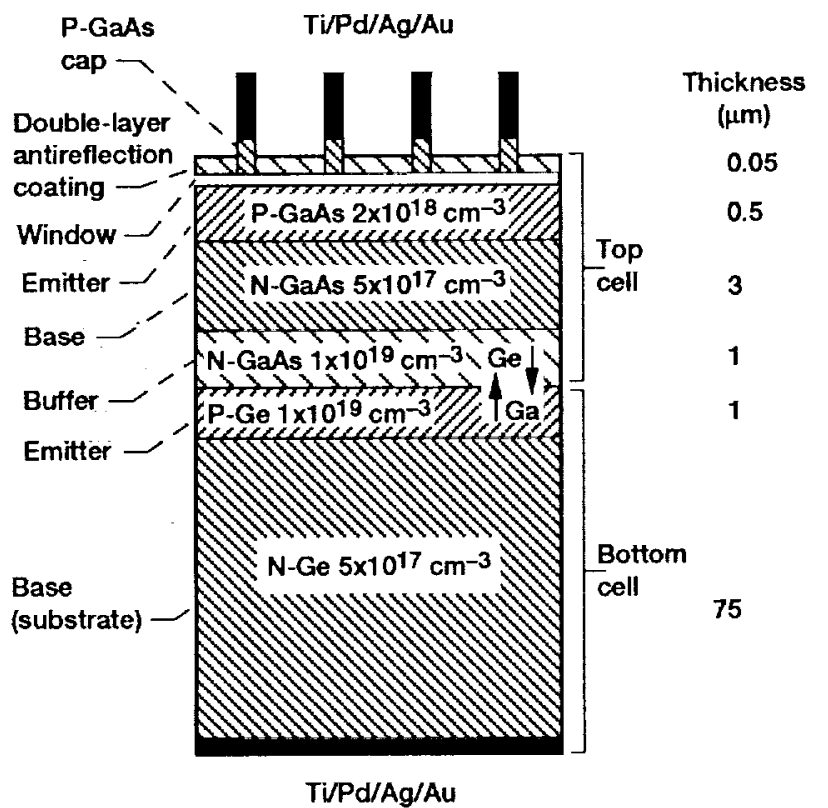

Figure 6.-Structure of GaAs/Ge cell.

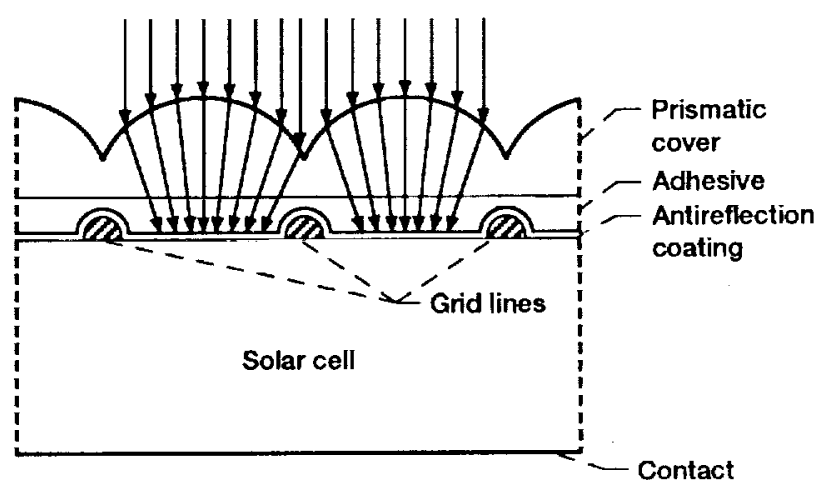

Figure 7.-Illustration of ENTECH prismatic cover slide concept to avoid grid-shading losses. Incoming light rays are bent toward the active cell area as they enter the thin molded cover.

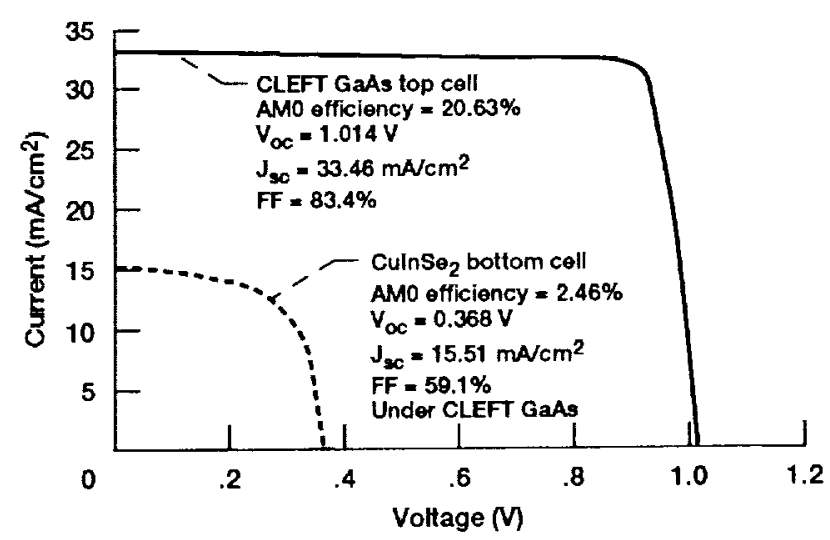

Figure 8.-I-V data on NASA-measured GaAs/CulnSe ${ }_{2}$ tandem cell. Total efficiency, $23.1 \%$ AMO; operating temperature, $25^{\circ} \mathrm{C}$; cell area, $4 \mathrm{~cm}^{2}$. Open-circuit voltage $\left(V_{o c}\right)$, short-circuit current density $\left(\mathrm{J}_{\mathrm{sc}}\right)$, fill factor (FF). 


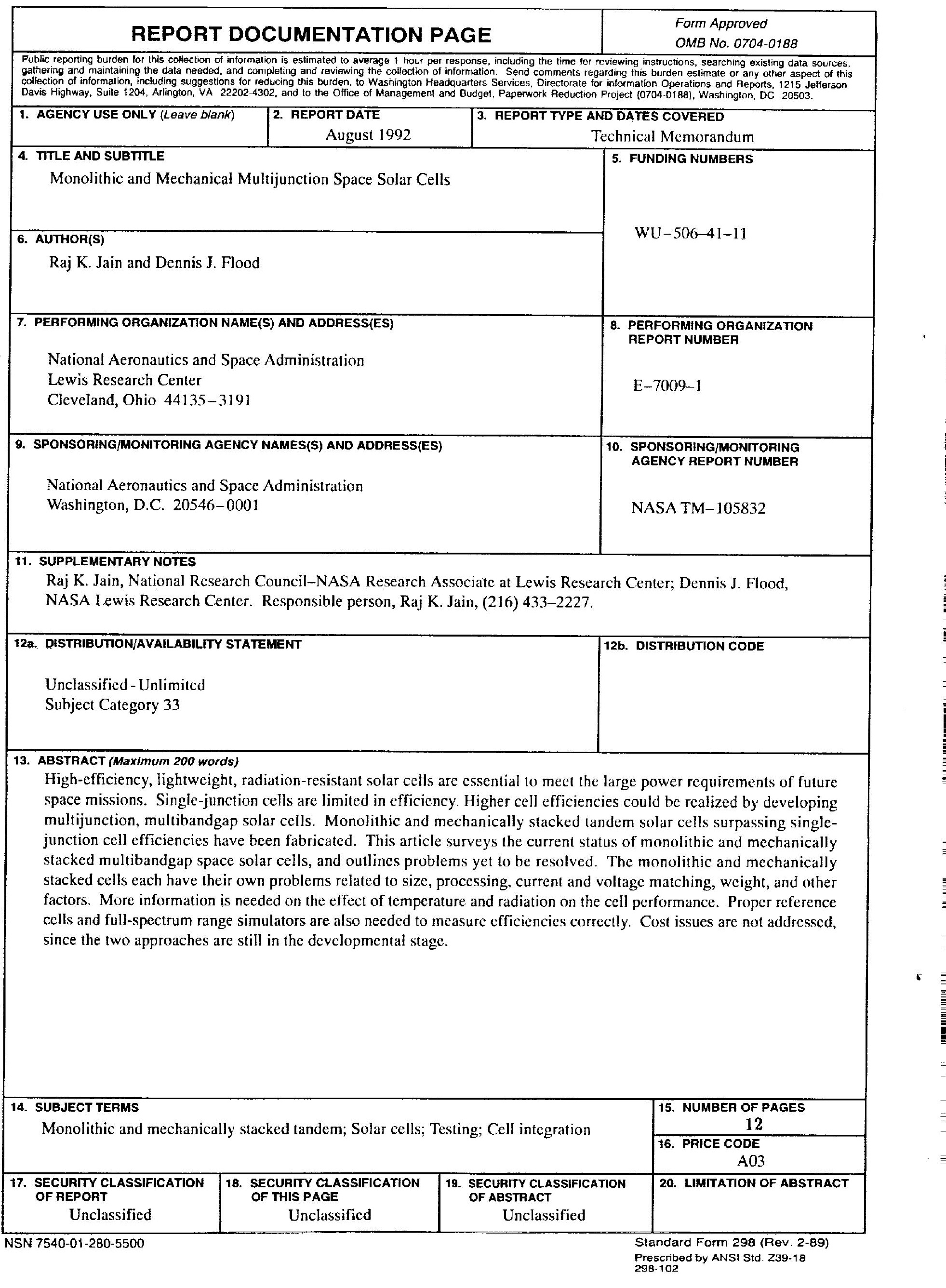

